\title{
Pengembangan Bahan Ajar E-Book Interaktif Berbantuan 3D Pageflip Profesional Pada Materi Aritmetika Sosial
}

\author{
Maila Sari ${ }^{1}$, Sri Rizki Murti ${ }^{2}$, Mhmd. Habibi ${ }^{3}$, Laswadi $^{4}$, Nur Rusliah $^{5}$ \\ 1,2,3,4,5 Institut Agama Islam Negeri Kerinci, Jl. Kapten Muradi Desa Sumur Gedang, Kota Sungai Penuh Jambi \\ mailasari821@gmail.com
}

\begin{abstract}
This research is a development research that adapts the ADDIE development model. There are 5 main stages in this research consisting of stages, analysis, design, development, implementation, and evaluation. The research instruments used are observation sheets, interviews and questionnaires. validated by a team of media experts and the material was then evaluated by the mathematics subject teacher and then tested in small groups of class VII students the results of this study were an interactive e-book teaching material that was operated using 3D pageflip profesional software. material expert. the results of the validation of the media expert obtained a score with an average of 0,86 and the material expert obtained an average of 0,802 which was categorized as valid. Furthermore, for the teacher's response, a percentage score was obtained $84,62 \%$ (very good) so that the interactive e-book teaching materials developed were feasible to be tested of class VII students obtained a percentage of $85,18 \%$ (very good). Based on the development process starting from the validation of media and research materials and results, it can be concluded that this e-book teaching material is very good to be used as teaching material or media that can used interactively in mathematics learning.
\end{abstract}

Keywords: Interactive e-book teaching materials, 3D pageflip profesional, social arithmetic.

\begin{abstract}
Abstrak
Penelitian ini merupakan penelitian pengembangan yang mengadaptasi model pengembangan ADDIE. Ada 5 tahapan utama dalam penelitian ini terdiri dari tahap, analisis (analysis), desain (design), pengembangan (development), penerapan (implementation), dan evaluasi (evaluation). Instrumen penelitian yang digunakan adalah lembar observasi, wawancara dan angket. Produk hasil pengembangan divalidasi oleh tim ahli media dan materi selanjutnya dinilain oleh guru mata pelajaran matematika dan kemudian diujicobakan pada kelompok kecil pada siswa kelas VII. Hasil dari penelitian ini adalah sebuah bahan ajar e-book interaktif yang operasikan menggunakan software 3D PageFlip Profesional. Produk tersebut divalidasi oleh ahli media dan ahli materi. Hasil validasi ahli media diperoleh skor dengan rata-rata 0,86 dan ahli materi diperoleh skor dengan rata-rata 0,802 dikategorikan valid. Selanjutnya, untuk tanggapan guru diperoleh skor persentase $83,33 \%$ (sangat baik) sehingga bahan ajar e-book interaktif yang dikembangkan layak untuk diujicobakan. Hasil respon siswa kelas VII diperoleh persentase $85,18 \%$ (sangat baik). Berdasarkan proses pengembangan mulai dari validasi media maupun materi dan hasil penelitian, secara keseluruhan disimpulkan bahwa bahan ajar e-book ini sangat baik digunakan sebagai bahan ajar atau media yang dapat digunakan secara interaktif dalam pembelajaran matematika. Kata kunci: Bahan Ajar E-book Interaktif, 3D Pageflip Profesional, Aritmetika Sosial
\end{abstract}

Copyright (c) 2021 Maila Sari, Sri Rizki Murti, Mhmd. Habibi, Laswadi, Nur Rusliah

$\triangle$ Corresponding author: Maila Sari

Email Address: mailasari821@gmail.com (Jl. Kapten Muradi Desa Sumur Gedang, Kota Sungai Penuh Jambi)

Received 27 Januari 2021, Accepted 27 Maret 2021, Published 27 Maret 2021

\section{PENDAHULUAN}

Dalam proses pembelajaran bahan ajar sangat penting bagi guru dan siswa, guru akan mengalami kesulitan dalam meningkatkan mutu pembelajaran jika tanpa disertai bahan ajar yang lengkap (Sadjati, 2019). Begitu pula, siswa akan mengalami kesulitan dalam belajar, seperti ketersediaan waktu dalam belajar digunakan oleh guru untuk menjelaskan materi. Adanya bahan ajar waktu yang tersedia untuk belajar dapat digunakan untuk diskusi dan membahas materi yang belum dipahami oleh siswa. Oleh karena itu, bahan ajar dapat meningkatkan kualitas dan keefektifan dalam proses belajar mengajar. Bahan ajar adalah suatu komponen yang sangat penting bagi guru dan siswa. Komponennya terdiri dari 
bahan ajar untuk siswa, bahan ajar utuk guru, dan lembar kerja siswa, yang terdiri dari susunan kompetensi inti, kompetensi dasar, dan indikator yang dapat mengembangkan kemampuan berfikir peserta didik, kebutuhan belajar, dan minat belajar peserta didik (Ibrohim, 2019). Untuk mengembangkan kemampuan peserta didik perlunya ada inovasi dan kreativitas terutama dari seorang guru untuk menciptakan suatu bahan ajar yang versi terbaru, misalnya sesuai perkembangan zaman, yaitu sesuai teknologi yang ada. Teknologi yang ada pada saat ini seperti buku yang berbentuk elektronik atau lebih dikenal dengan $e$-book.

E-book adalah salah satu teknologi yang memanfaatkan komputer untuk menayangkan informasi multimedia dalam bentuk ringkas dan dinamis (Nurdin, 2015). E-book juga dapat untuk membuat dan menggabungkan teks, gambar, audio, grafik maupun video, dengan menggunakan tool yang memungkinkan pemakai untuk berinteraksi (Rosida, Fadiawati, \& Jalmo, 2017.). E-book mudah dibawa kemanapun dan lebih mudah digunakan daripada buku paket (Hasbiyanti \& Khusnah, 2017).

Pengembangan bahan ajar sangat diperlukan sesuai dengan tuntutan kurikulum, karakteristik peserta didik dan dapat memecahkan masalah apalagi pada saat ini pandemi covid-19 penggunaan teknologi sangat diperlukan. Hasil observasi yang dilakukan dalam proses pembelajaran di SMPN 2 Kerinci guru hanya menggunakan bahan ajar berupa buku teks cetak, belum ada guru yang menggunakan bahan ajar berbentuk elektronik sedangkan di SMP tersebut terdapat Labor komputer tetapi belum dimanfaatkan untuk belajar Matematika. Berdasarkan proses pembelajaran siswa sering mengeluh, buku paket hanya berisi bacaan-bacaan dan latihan-latihan yang sulit serta kurang menariknya bahan ajar tersebut. sehingga proses pembelajaran menjadi membosankan dan pembelajaran menjadi lebih berpusat kepada guru. Hal ini diperkuat dengan penyebaran angket kepada siswa kelas VII bahwa 75\% menyatakan pembelajaran matematika membosankan, 70\% bahan ajar yang digunakan kurang menarik dan 70\% bahan ajar yang digunakan terlalu banyak soal. Berdasarkan hal tersebut bahan ajar mempunyai peranan penting dalam proses pembelajaran. Salah satu solusi adalah dengan mengembangkan bahan ajar berbentuk cetak menjadi berbentuk elektronik, yaitu bahan ajar $e$-book yang nantinya dapat menjadikan pembelajaran lebih fokus pada siswa dan menjadikan interaktif.

Materi yang dikembangkan adalah materi Aritmetika Sosial. Peserta didik harus memiliki pemahaman lebih, karena berkaitan erat dengan kehidupan sehari-hari tentang perekonomian (As'ari, 2017). Untuk meningkatkan pemahaman siswa pada materi Aritmetika Sosial siswa tentu harus menggunakan sumber pembelajaran yang baru (Prasetyo, Dwi, \& Retnawati, 2017). Berdasarkan hasil wawancara peserta didik Sering mengalami kesulitan dalam menyelesaikan soal cerita atau menyelesaikan permasalahan yang berhubungan dengan materi aritmetika sosial hal ini sesuai dengan hasil penelitian (Zanthy, 2020). Salah satunya adalah bahan ajar e-book interaktif. Bahan ajar e-book interaktif bantuan 3D Pageflip Profesional merupakan salah satu solusi yang tepat untuk memberikan suatu perangkat pembelajaran yang sesuai dengan perkembangan zaman saat ini.

$3 D$ Page flip Professional adalah aplikasi yang dapat digunakan untuk mengubah file pdf, word, power point, dan excel ke bentuk flipbooks Tiap digital halaman $p d f$ yang dihasilkan bisa diflip (bolak- 
Pengembangan Bahan Ajar E-Book Interaktif Berbantuan 3D Pageflip Profesional Pada Materi Aritmetika Sosial, Maila Sari, Sri Rizki Murti, Mhmd. Habibi, Laswadi, Nur Rusliah

balik) seperti buku yang sesungguhnya (Fitriyani, 2017). 3D Pageflip Profesional program unggulan yang khusus digunakan untuk menampilkan materi dalam bentuk buku elektronik yang bisa dilengkapi dengan audio, gambar, animasi bergerak dan video (Mindayula, 2017). Bahan ajar menggunakan $3 D$ Pageflip Profesional ini tidak hanya dapat dioperasikan melalui laptop saja, namun juga melalui Smartphone, Tablet dan Gadget dengan merubah format file atau .exe menjadi .3dp (Mindayula, 2017). Sehingga dimanapun dan kapanpun siswa dapat belajar secara mandiri.

Dari hasil penelitian yang dilakukan dengan judul bahan ajar $e$-book berbasis metakognisi pada materi reaksi redoks menggunakan 3D Pageflip menyatakan bahwa siswa memberikan respons sangat positif terhadap bahan ajar yang dikembangkan (Mindayula, 2017). Bahan ajar e-book dengan judul pengembangan bahan ajar e-book menggunakan model Problem Based Learning berbantuan 3D Pageflip Profesional pada materi transformasi di kelas IX SMA menyatakan bahwa respon siswa sangat baik tentang produk yang dihasilkan (Asmin, 2018).

Berdasarkan penelitian di atas, dengan adanya bahan ajar menggunakan teknologi menjadi salah satu cara agar meningkatkan hasil belajar siswa dan memberikan pengalaman baru kepada siswa dalam proses pembelajaran. Bahan ajar e-book setelah di ujicobakan memberikan respon yang sangat positif hal ini menandakan dengan bahan ajar e-book ini dapat meningkatkan motivasi siswa untuk belajar, atau siswa sangat antusias untuk mengikuti proses pembelajaran. Maka, dari uraian di atas peneliti bermaksud melakukan penelitian pengembangan yang berjudul "Pengembangan Bahan Ajar E-book Interaktif Berbantuan 3D Pageflip Profesional pada Materi Aritmetika Sosial”.

\section{METODE}

Metode pengembangan yang digunakan dalam penelitian ini adalah penelitian dan pengembangan (Research and Development). Model Pengembangan yang digunakan dalam pembuatan bahan ajar $e$ book interaktif berbantuan $3 D$ pageflip profesional adalah model ADDIE (Analyze, Design, Development, Implementation, Evaluation) dapat dilihat pada Gambar 1.

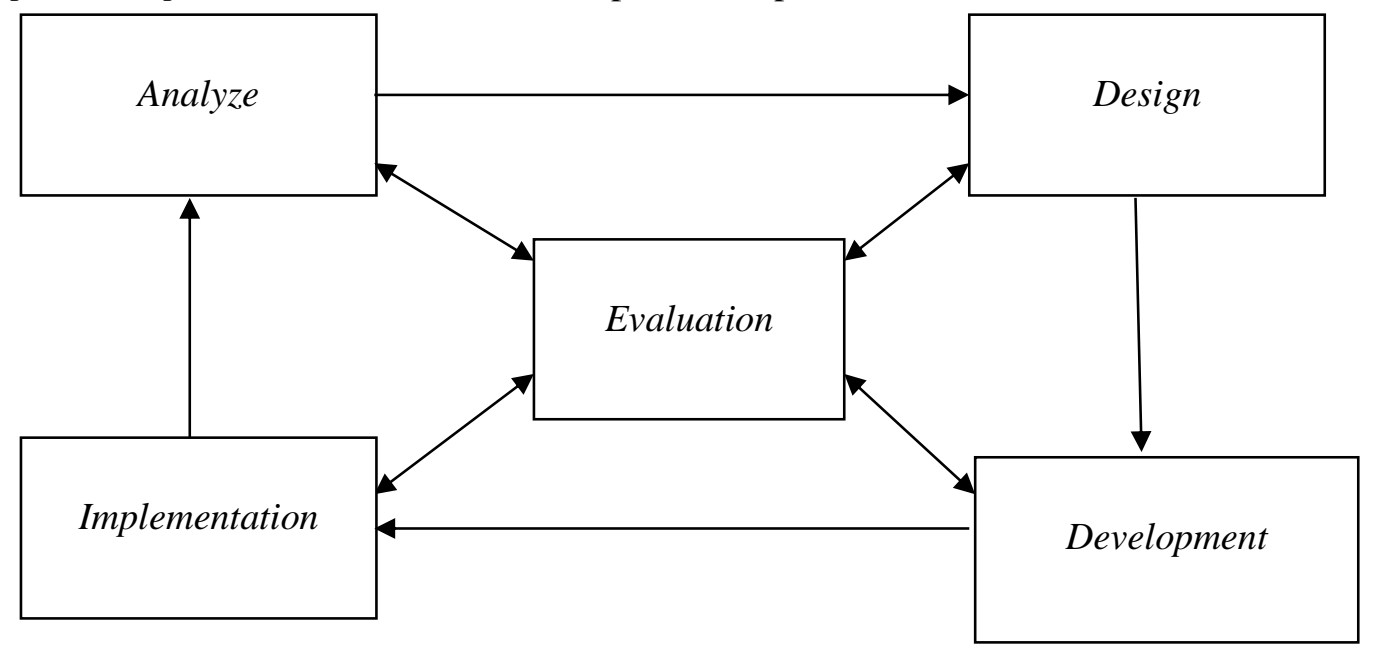

Gambar 1. Langkah-langkah Pengembangan ADDIE (Branch, 2009) 
Teknik yang digunakan dalam pengumpulan data berupa angket. Instrumen yang digunakan pada penelitian ini adalah angket validasi, penilaian dan responden. Angket validasi diberikan kepada ahli media dan ahli materi untuk divalidasi. Angket penilaian diberikan kepada guru untuk dinilai dan angket responden diberikan kepada siswa untuk mendapatkan respons siswa. Kemudian data yang diperoleh dianalisis berdasarkan ketentuan yang sudah ditetapkan. Data yang diperoleh berupa tanggapan, saran atau masukan yang diperoleh dari tim ahli yang digunakan untuk perbaikan produk, serta tanggapan dan saran dari guru. Penentuan klasifikasi validasi oleh ahli media, ahli materi dan penilaian oleh guru.

Data yang diperoleh dianalisis dan diarahkan untuk merevisi komponen perangkat pembelajaran yaitu bahan ajar yang sedang dikembangkan. Analisis data yang dilakukan dari Hasil validasi rancangan bahan ajar oleh validator dianalisis skala penilaian dengan skor 4 tertinggi dan menentukan nilai ratarata validitas tiap item menggunakan rumus (Azwar, 2013). Menentukan validitas bahan ajar menggunakan rumus (Walpole, 1992). Kriteria validitasnya di bawah 0,667 dinyatakan tidak valid, di atas 0,667 dinyatakan valid.

Hasil angket oleh respon guru dan respon siswa dianalisis dengan skala penilaian 4 tertinggi. Menentukan rata-rata skor tiap item menggunakan rumus dari (Walpole, 1992). Menentukan nilai praktikalitas menggunakan rumus dari (Purwanto, 2004) dengan kategori praktis pada 41\%-100\% (Riduwan, 2010).

\section{HASIL DAN DISKUSI}

\section{Proses Pengembangan Bahan Ajar E-book Interaktif}

Hasil dari penelitian ini adalah berupa produk yaitu bahan ajar e-book interaktif berbantuan $3 d$ pageflip profesional pada materi aritmetika sosial. Berikut deskripsi hasil pengembangan berdasarkan tahapan-tahapan yang dilakukan.

\section{Tahap Analisis}

Pada tahap ini Pada tahapan ini dilakukan analisis kurikulum, analisis kebutuhan, analisis karakteristik peserta didik dan analisis sumber daya yang tersedia. Adapun rincian sebagai berikut:

\section{Analisis Kurikulum}

Pada tahap ini dilakukan telaah terhadap kurikulum yang digunakan di SMPN 2 Kerinci yaitu kurikulum 2013 revisi 2017, khususnya pada materi Aritmetika Sosial kelas VII semester. Analisis terhadap kurikulum yang dimaksud adalah analisis terhadap kompetensi inti (KI), kompetensi dasar (KD), dan Tujuan pembelajaran. Pada kurikulum 2013 terdapat KI untuk materi Aritmetika Sosial yaitu memahami dan menerapkan pengetahuan (factual, konseptual, dan procedural) berdasarkan rasa ingin tahunya tentang ilmu pengetahuan, teknologi, seni, budaya terkait fenomena dan kejadian tampak mata Serta mengolah, menyaji, dan menalar dalam ranah konkret (menggunakan, mengurai, merangkai, memodifikasi, dan membuat) dan ranah abstrak (menulis, membaca, menghitung, menggambar, dan mengarang) sesuai dengan yang dipelajari di sekolah dan sumber lain yang sama dalam sudut pandang/teori. 
Berdasarkan KD untuk materi Aritmetika Sosial yaitu menganalisis Aritmetika Sosial (penjualan, pembelian, potongan, keuntungan, kerugian, bunga tunggal, persentase, bruto, neto, tara) Serta Menyelesaikan masalah berkaitan dengan Aritmetika Sosial (penjualan, pembelian, potongan, keuntungan, kerugian, bunga tunggal, persentase, bruto, neto, tara). Tujuan pembelajarannya adalah mengetahui dan memahami keuntungan dan kerugian, memahami persentase keuntungan, memahami persentase kerugian, menentukan bunga tunggal, memahami diskon (potongan) dan pajak, serta menentukan hubungan bruto, neto, dan tara.

Berdasarkan hasil analisis kurikulum K-13 pada KI, KD, dan Tujuan dapat disimpulkan bahwa bahan ajar harus dibuat sesuai dengan Kurikulum K-13 dengan KI, KD, dan Tujuan pada materi Aritmetika Sosial. Dimana siswa harus mampu menganalisis dan menyelesaikan masalah dalam kehidupan sehari-hari. Materi yang disajikan harus mengikuti prinsip-prinsip dan sesuai dengan tujuan pembelajaran yang ada pada silabus.

\section{Analisis Kebutuhan}

Berdasarkan hasil wawancara yang dilakukan dengan satu guru matematika SMPN 2 Kerinci, diperoleh beberapa informasi. Pertama, beberapa kendala yang ditemui oleh guru dalam pembelajaran adalah kemampuan peserta didik yang bervariasi sehingga dibutuhkan bahan ajar yang cocok untuk semua peserta didik. Kedua, guru lebih menggunakan cara model STAT karena dinilai lebih efektif dalam penggunaan waktu dan peserta didik lebih cepat mengerti yang diajarkan karena menyajikan kuis. Ketiga, bahan ajar yang digunakan hanya buku paket untuk guru dan siswa. Terakhir, guru setuju dengan pengembangan bahan ajar e-book interaktif berbantuan $3 D$ pageflip profesional.

Berdasarkan hasil angket yang diberikan kepada peserta didik bahan ajar yang digunakan sekarang kurang menarik dan terlalu banyak soal di dalam bahan ajar. Peserta didik menginginkan bahan ajar yang dikembangkan menarik dan berwarna. Rata-rata siswa menyukai warna biru, oleh karena itu bahan ajar e-book interaktif dibuat dengan background berwarna biru dan peserta didik sangat setuju dengan bahan ajar berbentuk elektronik. Oleh karena itu, bahan ajar e-book interaktif dibuat sesuai kebutuhan peserta didik untuk mempermudah memahami materi, adanya inovasi dan variasi dalam pembelajaran matematika, adanya umpan balik dari peserta didik dengan bahan ajar, dan membuat peserta didik menyukai pembelajaran matematika.

\section{Analisis Karakteristik Peserta Didik}

Karakteristik siswa berdasarkan kemampuan kognitif, motivasi belajar, nilai ulangan awal, dan media yang digunakan. Berdasarkan hasil pengamatan diperoleh kemampuan kognitif peserta didik dengan prestasi yang dimiliki kelompok tinggi dan sedang mendapatkan nilai yang bagus sedangkan prestasi yang dimiliki kelompok rendah mendapatkan nilai yang rendah. Hal ini berdasarkan hasil Nilai ulangan awal kelompok rendah juga mendapatkan nilai yang rendah, dimana salah satu penyebabnya adalah motivasi belajar masih kurang bersemangat untuk belajar matematika. Media yang digunakan untuk proses belajar mengajar adalah rol, pengggaris, kubus, balok, tabung, jam dan lain-lainnya. 
Berdasarkan hal di atas disimpulkan bahwa peserta didik memerlukan adanya variasi dalam pembelajaran adanya interaksi yang aktif antara guru dan siswa, meningkatkan kemampuan kognitif siswa, serta meningkatkan motivasi belajar siswa, sehingga penulis mengembangkan bahan ajar e-book interaktif berbantuan $3 D$ pageflip profesional.

\section{Sumber yang Tersedia}

Sumber daya yang tersedia di SMPN 2 Kerinci dilihat dari sumber konten, sumber daya manusia, dan sumber daya teknologi. Sumber konten yang dimiliki di SMPN 2 Kerinci setiap guru dan siswa memiliki buku paket sebagai bahan ajar. Sumber daya manusia yang dimiliki sekolah, hanya satu guru matematika yang mengajar di SMPN 2 Kerinci. Sumber daya teknologi yang dimiliki SMPN 2 Kerinci yaitu laboratorium Komputer, kondisi laboratorium layak digunakan dengan jumlah komputer 20 buah tapi tidak dapat beroperasi semua, yang dapat dioperasikan hanya 14 buah komputer. Berdasarkan hasil pengamatan sumber yang tersedia penelitian dapat dilakukan di SMPN 2 Kerinci, dimana penelitian dilakukan di kelas VII.

\section{Tahap Desain}

Hasil pada tahap analisis digunakan sebagai landasan pada tahap desain. Pada tahap ini hal yang pertama kali dilakukan adalah mendesain bahan ajar e-book interaktif, yaitu membuat flowchart yang akan digunakan pada proses produksi. Flowchart atau diagram alur merupakan sebuah diagram dengan simbol-simbol grafis untuk menampilkan langkah-langkah dalam bentuk kotak beserta urutannya dengan menghubungkan masing-masing langkah tersebut, diagram ini bisa memberi solusi selangkah demi selangkah untuk penyelesaian masalah yang ada dalam proses. Dari Flowchart dikembangkan menjadi storyboard, Setelah itu menyiapkan angket yang diperlukan.

\section{Tahap Pengembangan}

Produk yang dihasil kan berupa bahan ajar yang terdiri dari teks, gambar, animasi serta video, yang mana penggunaannya dibuka atau di operasikan dengan laptop atau komputer. Penggunaannya dapat juga menggunakan smartphone, gadget, atau tablets. Berikut beberapa hasil dari produk yang di kembangkan. Halaman Depan Terdapat beberapa gambar di bahan ajar e-book interaktif, gambar tersebut mewakilkan sub-materi yang akan dipelajari pada materi Aritmetika Sosial yaitu gambar untung dan rugi, bank, diskon, dan bruto, tara, neto. Tampilan cover dapat dilihat pada gambar berikut ini:

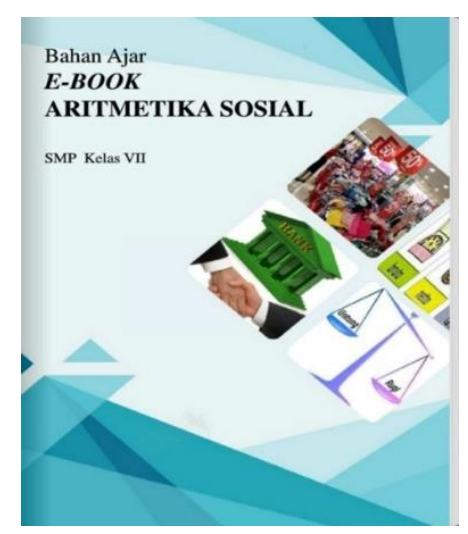

Gambar 2. Halaman Pembuka 
Pengembangan Bahan Ajar E-Book Interaktif Berbantuan 3D Pageflip Profesional Pada Materi Aritmetika Sosial, Maila Sari, Sri Rizki Murti, Mhmd. Habibi, Laswadi, Nur Rusliah

Materi Keuntungan dan Kerugian Pada materi ini terdapat teks, gambar, animasi video dan jawaban dari contoh yang diisikan oleh peserta didik. Gambar, animasi video dan contoh yang diisikan oleh peser didik membuat interaksi dengan penggunanya sehingga pembelajaran menjadi efektif. Begitu pun materi lainnya yaitu materi bunga tunggal. materi bruto, tara dan neto. Seperti yang terlihat pada gambar berikut ini:

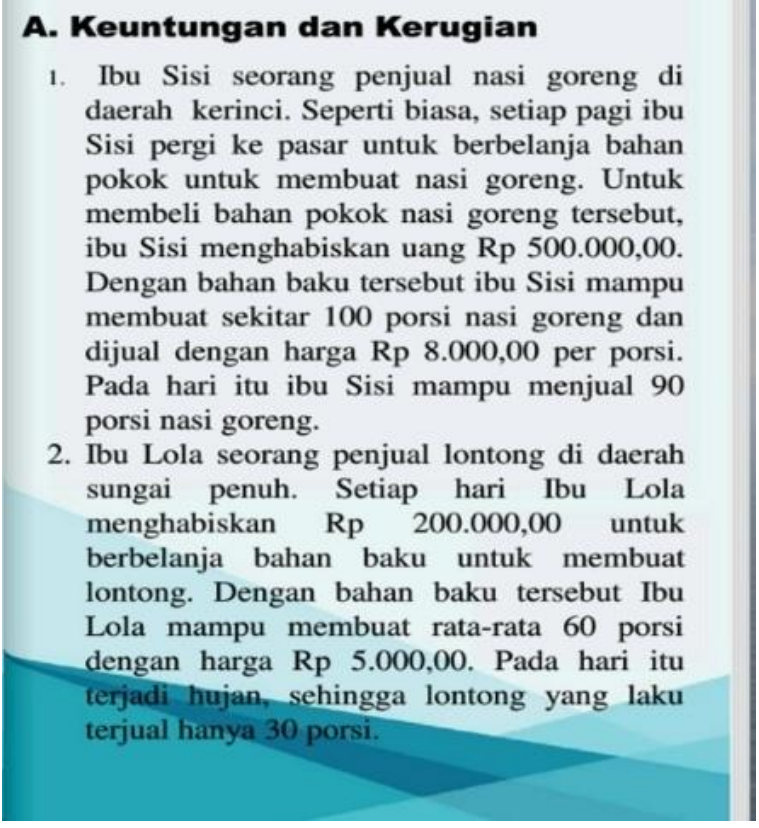

Gambar 3. Tampilan Materi Keuntungan dan Kerugian

Latihan Soal Pada halaman ini terdapat latihan mengenai keuntungan atau kerugian, persentase keuntungan atau kerugian, bunga tunggal, pajak, diskon, dan bruto, tara dan neto yang berbentuk flash dengan jawaban pilihan ganda. Kemudian peserta didik dapat memilih jawaban yang diperoleh oleh peserta didik, setelah mengerjakannya hasil dari jawabannya akan keluar sehingga peserta didik dapat mengetahui nilai yang diperolehnya. Seperti yang terlihat pada gambar berikut ini:

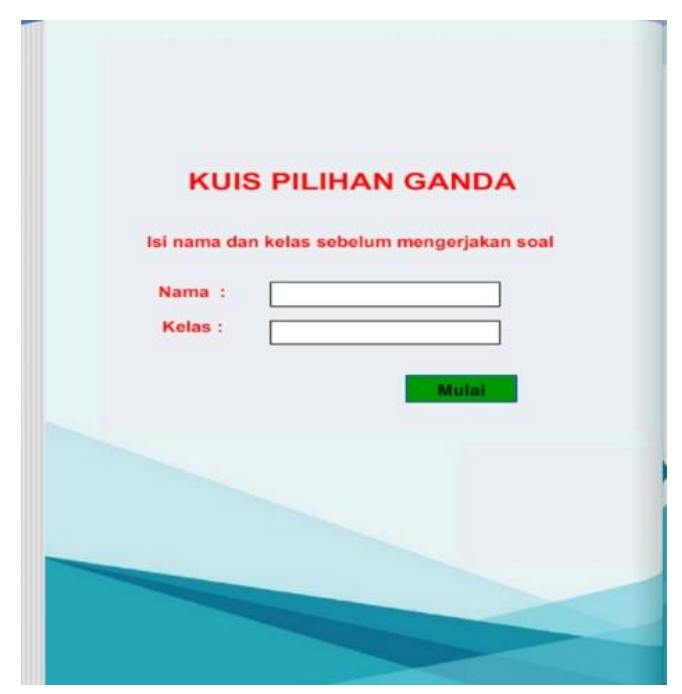

Gambar 4. Tampilan Latihan Soal 


\section{Validitas}

Bahan ajar yang sudah dibuat kemudian divalidasi oleh ahli media. Setelah ahli media melihat dan menyimak bahan ajar yang sudah di kembangkan, selanjutnya ahli media menilai bahan ajar dengan mengisi angket penilaian media yang sudah dibuat. Dari hasil penilaian angket didapat saran dan perbaikan bahan ajar yang dikembangkan sehingga mendapatkan data.

Bahan ajar yang sudah dibuat dan divalidasi ahli media kemudian divalidasi oleh ahli materi yang bertujuan melihat apakah materi yang digunakan sudah sesuai dengan kurikulum 2013 dan bisa di di pelajar oleh siswa. Setelah ahli materi melihat dan menyimak materi di bahan ajar yang sudah di kembangkan dan disudah di validasi oleh ahli media, selanjutnya ahli materi menilai materi di dalam bahan ajar dengan mengisi angket penilaian materi yang sudah dibuat, dari hasil penilaian angket didapat saran dan perbaikan materi di dalam bahan ajar yang dikembangkan sehingga mendapatkan data. Berikut ini hasil validasi ahli media dan ahli materi pada tabel 1 dan tabel 2 berikut:

Tabel 1. Hasil Validasi Ahli Media

\begin{tabular}{|c|c|c|c|}
\hline No. & Pernyataan & $\begin{array}{c}\text { Indeks } \\
\text { Validitas }\end{array}$ & Kategori \\
\hline I. & Aspek Tampilan & & \\
\hline 1. & $\begin{array}{l}\text { Desain sampul menggunakan kombinasi warna yang } \\
\text { menarik. }\end{array}$ & 1 & Valid \\
\hline 2. & Desain sampul mewakili isi bahan ajar e-book interaktif. & 1 & Valid \\
\hline 3. & $\begin{array}{l}\text { Bagian judul dan bagian yang membutuhkan penekanan } \\
\text { dicetak tebal dengan warna yang lebih mencolok. }\end{array}$ & 0,667 & Valid \\
\hline 4. & $\begin{array}{l}\text { Huruf yang digunakan dalam bahan ajar e-book } \\
\text { sederhana dan mudah dibaca. }\end{array}$ & 1 & Valid \\
\hline 5. & $\begin{array}{l}\text { Permasalahan, materi dan soal diperjelas dengan } \\
\text { gambar yang relevan dan menarik. }\end{array}$ & 1 & \\
\hline 6. & Tata letak teks dan gambar sudah tepat. & 0,667 & \\
\hline 7. & Keserasian ukuran teks dan gambar sudah tepat. & 1 & \\
\hline II. & Aspek Bahasa & & \\
\hline 8. & $\begin{array}{l}\text { Bahasa yang digunakan pada bahan ajar e-book } \\
\text { interaktif sesuai dengan kaidah bahasa Indonesia yang } \\
\text { baik dan benar. }\end{array}$ & 0,667 & Valid \\
\hline 9. & $\begin{array}{l}\text { Bahasa yang digunakan pada bahan ajar e-book } \\
\text { interaktif mudah dipahami. }\end{array}$ & 1 & Valid \\
\hline 10. & $\begin{array}{l}\text { Bahasa yang digunakan disesuaikan dengan tingkat } \\
\text { komunikasi peserta didik. }\end{array}$ & 1 & Valid \\
\hline 11. & $\begin{array}{l}\text { Penulisan simbol sesuai dengan kaidah penulisan yang } \\
\text { benar. }\end{array}$ & 0,667 & Valid \\
\hline \multirow[t]{2}{*}{12.} & $\begin{array}{l}\text { Penggunaan simbol dan bahasa asing sesuai dengan } \\
\text { kaidah penulisan yang benar. }\end{array}$ & 0,667 & Valid \\
\hline & Rata-rata Indeks Validitas & 0,86 & Valid \\
\hline
\end{tabular}


Pengembangan Bahan Ajar E-Book Interaktif Berbantuan 3D Pageflip Profesional Pada Materi Aritmetika Sosial, Maila

Tabel 2. Hasil Validasi Ahli Materi

\begin{tabular}{|c|c|c|c|}
\hline No. & Pernyataan & Indeks Validitas & Kategori \\
\hline I & Aspek Didaktik atau Penyajian & & \\
\hline 1 & $\begin{array}{l}\text { Permasalahan yang disajikan adalah permasalahan yang } \\
\text { dapat dijumpai oleh peserta didik dalam kehidupan } \\
\text { sehari-hari. }\end{array}$ & 0,667 & Valid \\
\hline 2 & $\begin{array}{l}\text { Kesesuaian soal dengan pembahasan pada bahan ajar } e \text { - } \\
\text { book. }\end{array}$ & 1 & Valid \\
\hline 3 & $\begin{array}{l}\text { Penggunaan mandiri untuk pengguna bahan ajar } e \text {-book } \\
\text { interaktif. }\end{array}$ & 0,667 & Valid \\
\hline 4 & $\begin{array}{l}\text { Kesesuaian gambar, video animasi dengan materi di } \\
\text { dalam bahan ajar e-book interaktif. }\end{array}$ & 0,667 & Valid \\
\hline II & Aspek Materi atau Isi & & \\
\hline 5 & $\begin{array}{l}\text { Materi yang disajikan dalam bahan ajar e-book sesuai } \\
\text { dengan kompetensi inti dan kompetensi dasar. }\end{array}$ & 1 & Valid \\
\hline 6 & $\begin{array}{l}\text { Materi memuat fakta, konsep, prinsip dan prosedur yang } \\
\text { relevan dengan tujuan pembelajaran. }\end{array}$ & 1 & Valid \\
\hline 7 & $\begin{array}{l}\text { Materi yang disajikan memadai untuk mencapai } \\
\text { indikator pencapaian kompetensi yang telah ditetapkan. }\end{array}$ & 0,667 & Valid \\
\hline 8 & $\begin{array}{l}\text { Materi yang disajikan secara sistematis } \\
\text { memperhatikan urutan } \\
\text { memprasyarati. }\end{array}$ & 0,667 & Valid \\
\hline 9 & $\begin{array}{l}\text { Materi disajikan secara sistematis dengan } \\
\text { memperhatikan tingkat kesulitan materi. }\end{array}$ & 0,667 & Valid \\
\hline 10 & $\begin{array}{l}\text { Substansi materi yang disajikan benar berdasarkan ilmu } \\
\text { matematika. }\end{array}$ & 1 & Valid \\
\hline \multicolumn{2}{|c|}{ Rata-rata Indeks Validitas } & 0,802 & Valid \\
\hline
\end{tabular}

Bahan ajar e-book terlebih dahulu divalidasi oleh ali media dan ahli materi serta meminta tanggapan atau penilaian dari produk yang sudah di kembangkan. Hasil validasi dari ahli media dan ahli materi yaitu bahan ajar $e$-book interaktif ini dinyatakan valid dengan rata-rata indeks validitas 0,86 dan 0,802. maka, bahan ajar e-book interaktif di katakan valid, karena bahan ajar e-book sudah melalui tahap validasi yang sudah di lakukan oleh ahli media dan ahli materi.

Sehingga tim ahli mengatakan bahwa produk atau bahan ajar $e$-book dapat digunakan dengan beberapa komentar dan saran dari validator. Berikut revisi perbaikan produk dari ahli media dan ahli materi

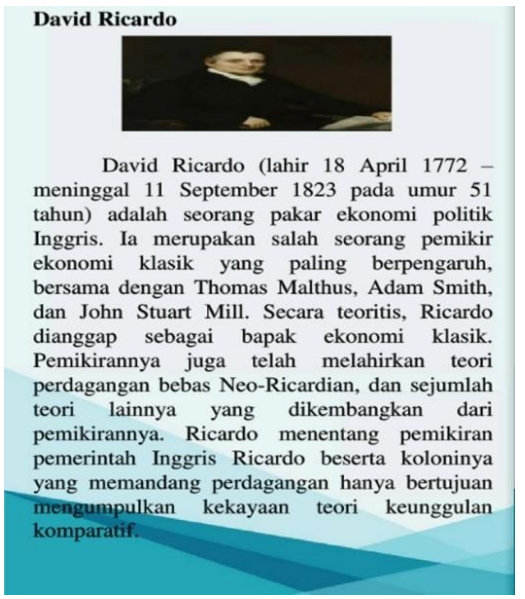

Gambar 4. Penambahan Tokoh Matematika 
Tokoh matematika pada materi aritmetika sosial adalah david Ricardo beliau diaggap sebagai bapak ekonomi klasik. Penambahan tokoh matematika dilakukan agar peserta didik termotivasi belajar dan mengingat kembali sejarah penemuan tentang ilmu-ilmu matematika.

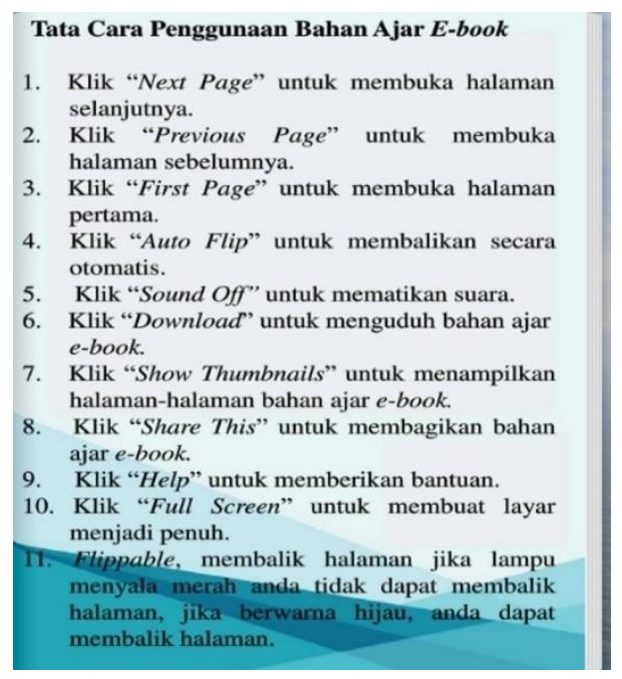

Gambar 5. Penambahan Aturan Penggunaan Bahan Ajar

Penambahan aturan penggunaan bahan ajar dilakukan agar guru dan peserta didik mudah menggunakannya. Tombol-tombol apa saja yang ada di dalam bahan ajar tersebut kemudian dijelaskan penggunaanya dijelaskan. Tombol-tombolnya seperti next, first page, download, full screen, previous page, flappable, share this, show thumbnails, auto flip, sound off, and help.

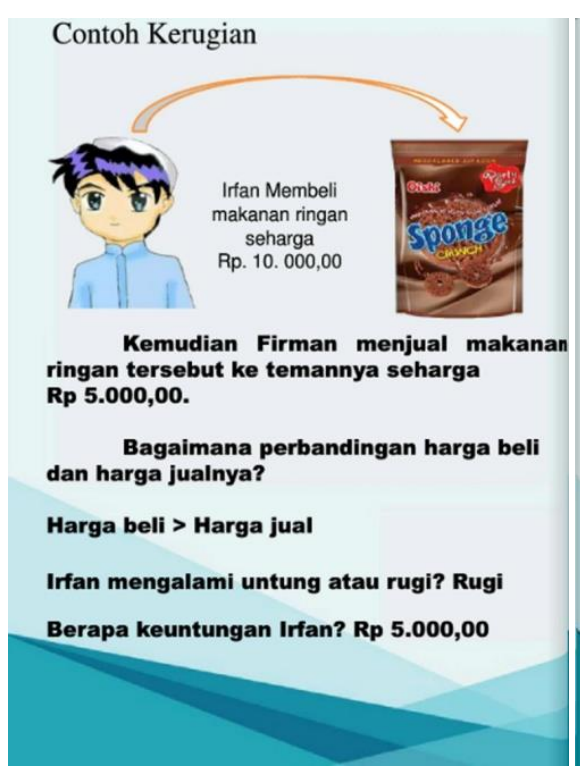

Gambar 6. Sebelum Revisi

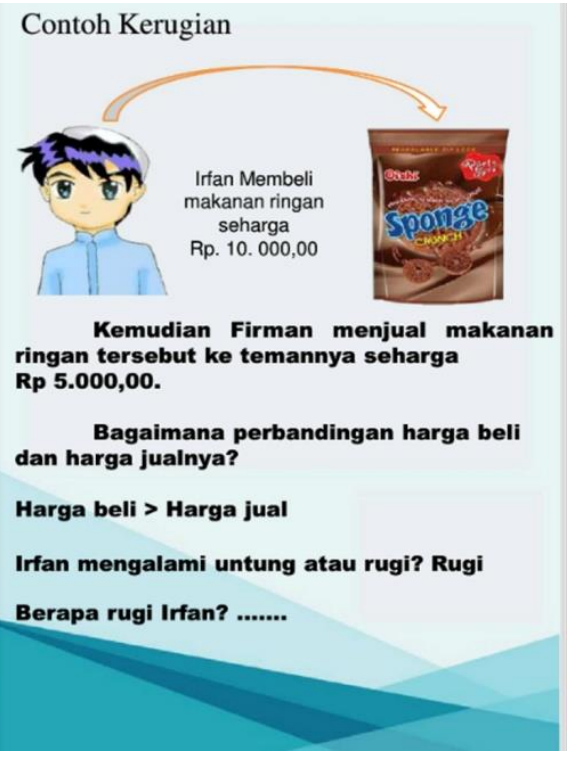

Gambar 7. Sesudah Revisi

Penambahan contoh soal dilakukan karena pada bahan ajar e-book interaktif sebelumnya soal terlalu monoton tanpa ada interaksi antara teknologi dan pemakainya. Kemudian peneliti memasukkan gambar, nama dan soal yang sering dilakukan oleh peserta didik dalam kehidupan sehari-harinya agar peserta didik semangat untuk belajar terutama pembelajaran matematika oleh karena itu, bahan ajar dibuat semanarik mungkin. 
Pengembangan Bahan Ajar E-Book Interaktif Berbantuan 3D Pageflip Profesional Pada Materi Aritmetika Sosial, Maila Sari, Sri Rizki Murti, Mhmd. Habibi, Laswadi, Nur Rusliah

\section{Praktikalitas}

Setelah membuat produk maka dilakukan ujicoba terhadap siswa (responden). Ujicoba dilakukan di SMP Negeri 2 Kerinci pada kelas VII. Hasil dari penilaian dari guru didapat yaitu bahan ajar e-book ini dinyatakan dalam kategori sangat baik dengan rata-rata indeks validitas $84,16 \%$. Setelah mendapatkan hasil dari penilaian dari guru maka di lakukan uji coba produk atau penerapan produk bahan ajar e-book interaktif di dalam kelas untuk mendapat data tanggapan atau respons dari siswa terhadap dari bahan ajar e-book interaktif yang di kembangkan. Dari hasil penerapan atau uji coba produk bahan ajar e-book ini di dapat hasil adalah "sangat baik" dengan nilai presentase 85,18\% dari 9 orang siswa. Berdasarkan data dari angket respons siswa di dapat nilai kelayakan adalah $85,18 \%$, sehingga bahan ajar e-book ini sangat baik dan positif, ini juga sependapat dengan Azwar (2013) menyatakan efektif dan positif jika jawaban siswa terhadap pernyataan positif untuk setiap pernyataan yang direspons pada setiap komponen pembelajaran diperoleh persentase.

Tabel 3. Hasil Analisis Respon Guru

\begin{tabular}{|c|l|c|c|c|}
\hline No. & \multicolumn{1}{|c|}{ Aspek yang Dinilai } & Rata-rata & Persentase & Kategori \\
\hline 1. & Kemudahan Penggunaan & 3,33 & $83,33 \%$ & Sangat Praktis \\
\hline 2. & Efisiensi Waktu & 3 & $75 \%$ & Praktis \\
\hline 3. & Ekivalensi Bahan Ajar E-book & 3,67 & $91,67 \%$ & Sangat Praktis \\
\hline \multicolumn{2}{|l|}{ Rata-rata keseluruhan } & $\mathbf{3 , 3 8}$ & $\mathbf{8 4 , 6 2}$ & Sangat Praktis \\
\hline
\end{tabular}

Tabel 4. Hasil Analisis Respon Siswa

\begin{tabular}{|c|l|c|c|c|}
\hline No. & \multicolumn{1}{|c|}{ Aspek yang Dinilai } & Rata-rata & Persentase & Kategori \\
\hline 1. & Kemudahan Penggunaan & 3,39 & $84,72 \%$ & Sangat Praktis \\
\hline 2. & Efisiensi Waktu & 3,22 & $80,56 \%$ & Sangat Praktis \\
\hline 3. & $\begin{array}{l}\text { Manfaat Bahan Ajar E-book } \\
\text { Interaktif }\end{array}$ & 3,52 & $87,96 \%$ & Sangat Praktis \\
\hline Rata-rata keseluruhan & $\mathbf{3 , 4 1}$ & $\mathbf{8 5 , 1 8 \%}$ & Sangat Praktis \\
\hline
\end{tabular}

Pada tabel 3, terlihat bahwa rata-rata tingkat kepraktisan bahan ajar e-book interaktif menurut respon guru adalah $84,62 \%$. Pada tabel 4 , terlihat bahwa rata-rata tingkat kepraktisan bahan ajar e-book interaktif menurut respon peserta didik adalah $85,18 \%$. Jadi, dapat disimpulkan bahan ajar e-book interaktif sangat praktis menurut guru dan respon peserta didik hal ini bahan ajar e-book dapat digunakan untuk proses pembelajaran.

\section{DISKUSI}

Pembahasan Proses pengembangan bahan ajar e-book interaktif meliputi tahapan analisis kebutuhan siswa, analisis kurikulum, analisis karakteristik siswa, dan sumber yang tersedia kemudian tahapan mendesain bahan ajar e-book menggunakan bantuan software Adobe Photoshop CS3 dan Software power points. Dalam proses pembuatan desain terdiri dari pembuatan background, dan membuat desain latar belakang isi dari bahan ajar, mulai dari desain cover, halaman isi dan backcover. Setelah proses mendesain barulah membuat bahan ajar e-book menggunakan 3D Pageflip Profesional. 
Dalam 3D pageflip hanya menambahkan video animasi dan flash, dan lainnya. Sehingga menjadi bahan ajar $e$-book.

Bahan ajar e-book ini memiliki struktur penyusunan terdiri dari halaman depan, halaman kata penghantar, daftar isi, kompetensi inti, kompetensi dasar, indikator pembelajaran, tujuan pembelajaran, materi, uji kompetensi dan halaman riwayat penulis. Dalam materi terdiri dari gambar, video animasi dan flash, yang bertujuan memudahkan siswa dalam memahami materi. Bahan ajar e-book ini menggunakan materi Aritmetika sosial kelas VII SMP. Bahan ajar e-book ini dirancang untuk memberikan sesuatu yang baru dalam belajar mengajar di dalam kelas sehingga belajar tidak menjadi membosankan.

Dalam bahan ajar e-book juga menampilkan video pembelajaran materi aritmetika sosial agar siswa mampu belajar mandiri dan lebih memahami materi. Bukan saja video dalam bahan ajar e-book juga terdapat flash yang memberikan nilai atau jawaban langsung ketika siswa sudah selesai dalam menjawab soal uji kompetensi. Dengan adanya video dan flash tentunya memberikan pengalaman baru bagi siswa dalam belajar dan bisa meningkatkan motivasi siswa dalam belajar di dalam kelas. Setelah media pembelajaran bahan ajar e-book interaktif dibuat, selanjutnya bahan ajar e-book di validasi oleh tim ahli. Secara umum rata-rata indeks kevalidan bahan ajar pada semua aspek adalah 0,86 dan 0,802 dengan kriteria valid sehingga dapat direkomendasikan untuk digunakan dalam proses pembelajaran. Hal ini sesuai dengan pendapat (Sukardi, 2008) yang mengatakan bahwa perangkat pembelajaran dikatakan valid jika perangkat pembelajaran yang dikembangkan berdasarkan prosedur pengembangan perangkat dan telah divalidasi oleh validator dengan penilaian valid serta memberikan rekomendasi untuk dipakai.

Kriteria yang dipakai untuk menilai praktikalitas dalam pengembangan perangkat ini adalah uji coba perorangan dan uji coba kelompok kecil, kemudahan yang mengacu kepada mudahnya perangkat tersebut digunakan guru dan dipahami oleh peserta didik. serta cukupnya waktu yang disediakan dalam menggunakan perangkat tersebut. Tingkat kepraktisan perangkat ini didapatkan melalui pemberian angket kepada pengguna perangkat yaitu guru dan peserta didik. Hal ini sejalan pendapat Nieveen dalam (Plomp, 2013) yang menyatakan bahwa sebuah perangkat pembelajaran dikatakan praktis jika perangkat tersebut dapat digunakan dengan mudah oleh guru dan peserta didik dalam pembelajaran.

\section{KESIMPULAN}

Bahan ajar e-book ini dikembangkan dengan menggunakan model desain pengembangan ADDIE, dengan tahapan: (1) Analisis meliputi analisis kebutuhan, kurikulum, karakteristik peserta didik dan sumber yang tersedia (2) Desain meliputi pembuatan flowchart dan storyboard, (3) Pengembangan meliputi pembuatan produk yang kemudian divalidasi oleh tim ahli dan ahli materi, dinilai dengan perolehan rata-rata indeks validitas 0,86 dan 0,802 . Kemudian penilaian oleh guru dengan rata-rata $84,42 \%$ yang berada pada tingkat kategori "sangat baik" terhadap bahan ajar e-book interaktif ini, (4) Implementasi, pada tahap ini dilakukan ujicoba kelompok, dan (5) Evaluasi, yang bisa dilakukan pada 
Pengembangan Bahan Ajar E-Book Interaktif Berbantuan 3D Pageflip Profesional Pada Materi Aritmetika Sosial, Maila Sari, Sri Rizki Murti, Mhmd. Habibi, Laswadi, Nur Rusliah

tiap tahapan. Berdasarkan penelitian diketahui respons siswa kelas VIII SMP Negeri Kerinci pada materi aritmetika sosial dengan persentase kelayakan oleh siswa $85,14 \%$ (sangat baik) yang menyatakan bahwa siswa memberikan respons sangat positif terhadap bahan ajar yang dikembangkan.

\section{UCAPAN TERIMA KASIH}

Terima kasih penulis ucapkan kepada Bapak/Ibu yang sudah membantu dalam menyelesaikan penelitian hingga dapat dipublikasikannya artikel ini pada Jurnal Cendekia: Jurnal Pendidikan Matematika.

\section{REFERENSI}

Asmin, D. (2018). Pengembangan Bahan Ajar E-book Menggunakan Model Problem Based Learning Berbantuan 3D Pageflip Profesional Pada Materi Transformasi Di Kelas XI SMA. Universitas Jambi.

Azwar, S. 2013. Validitas dan Reliabilitas. Yogyakarta: Pustaka Pelajar.

Branch, R. M. (n.d.). Instructional Design: The ADDIE Approach. (https://doi.org/10.1007/978-0-38709506-6).

Fitriyani. (2017). Pembelajaran Menggunakan Media 3D Pageflip Profesional dan Media Camtasia studio 8 Pada Materi Larutan Elektrolit dan Non Elektolit Di Kelas X SMA Islam Al-Arief Muara Jambi.

Hasbiyanti, H., \& Khusnah, L. (2017). Penerapan Media E-book Berekstensi EPUB untuk Meningkatkan Minat dan Hasil Belajar Siswa SMP pada Mate Pelajaran IPA. Jurnal Pena Sains, 4(1), 0-5. (https://core.ac.uk/download/pdf/304219348.pdf). diakses 28 September 2020.

Ibrohim, S. (2019). Pengembangan Elektronik Modul Menggunakan Aplikasi 3D Pageflip Profesional pada Tema Ekosistem untuk Kelas V SD/MI. Universitas Islam Negeri Raden Intan Lampung.

Mindayula, E. (2017). Pengembangan Bahan Ajar E-book Berbasis Metekognisi Menggunakan 3D Pageflip Pada Materi Reaksi Redoks Di Kelas X MIPA SMA Negeri 1 Muaro Jambi.

Nurdin, A. (2015). Pengembangan E-book Interaktif Untuk Meningkatkan Keterampilan Berpikir Kritis Siswa pada Pokok Bahasan Pencemaran dan Perubahan Lingkungan di Kelas X SMA Negeri 1 Waled. Institut Agama Islam Negeri Syekh Nurjati.

Plomp, Tjeerd dan Neinke Nieveen. 2013. Educational Design Research, Part A: An Introduction. Enchede: SLO.

Prasetyo, Jeni Dwi, \& Heri Retnawati. (2017). Pengembangan Perangkat Pembelajaran Matematika Berbasis Masalah Pada Materi Aritmatika Sosial Untuk Siswa SMP Kelas VII. 6(3), 13-23.

Purwanto, N. 2004. Prinsip-prinsip dan Teknik Evaluasi Pengajaran. Bandung: Remaja Rosdakarya. Rosida, Fadiawati, N., \& Jalmo, T. 2017. Efektivitas Penggunaan Bahan Ajar E-book Interaktif Dalam Menumbuhkan Keterampilan Berpikir Kritis Siswa. 35-45.

Sadjati, I. M. 2019. Hakikat Bahan Ajar. 1-62. (http://repository.ut.ac.id/4157/1/IDIK4009-M1.pdf). diakses 28 September 2020. 
Sugiman, Sumardyono, \& Marfuah. (2016). Karakteristik Siswa SMP dan Bilangan. Direktorat Jenderal Guru dan Tenaga Kependidikan.

Sukardi. 2008. Evaluasi Pendidikan: Prinsip dan Operasionalnya. Yogyakarta: Bumi Aksara.

Walpole, Ronald E. 1992. Pengantar Statistika. Jakarta: Gramedia Pustaka Utama.

Zanthy, L.S., \& Yunia, N. (2020). Kesalahan Siswa SMP dalam Menyelesaikan Soal Cerita pada Materi Aritmatika Sosial. Jurnal Teorema: Teori dan Riset Matematika, 5(1), 105-116. (https://jurnal.unigal.ac.id/index.php/teorema/article/view/3206). diakses 19 November 2020 